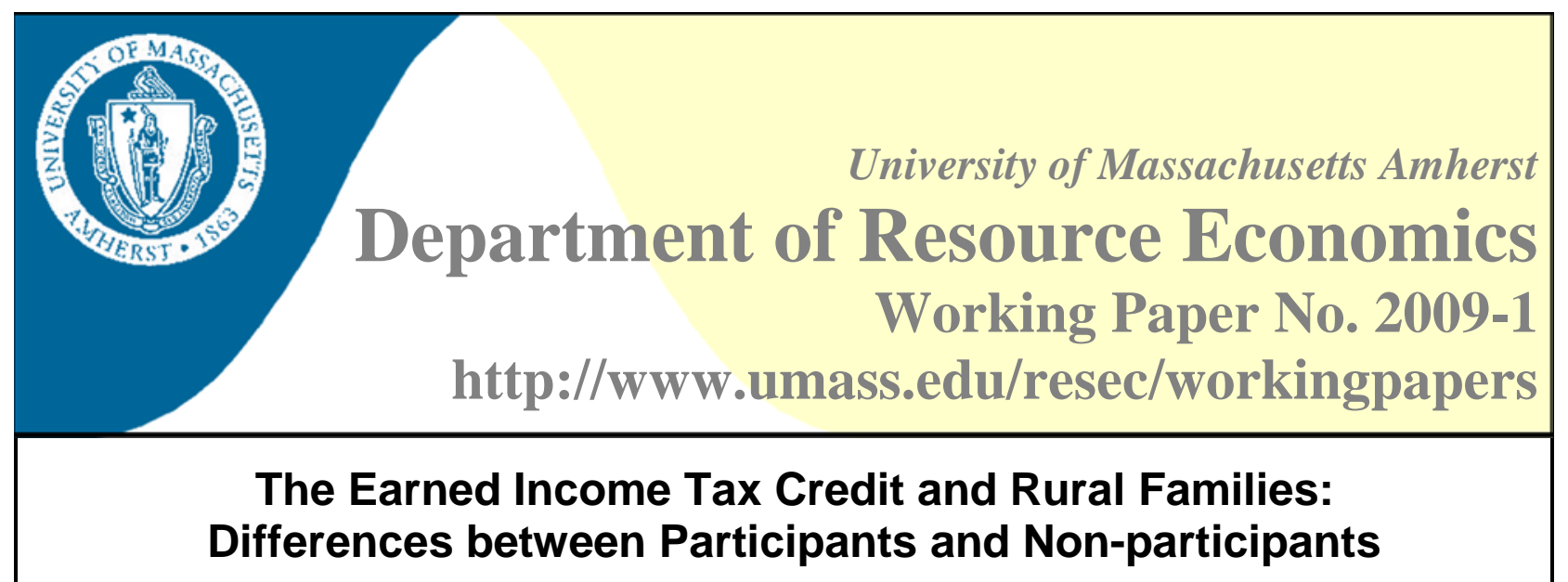

Abstract:

\author{
Sheila Mammen ${ }^{1}$, Frances C. Lawrence ${ }^{2}$, Peter St. Marie $^{3}$, \\ Ann A. Berry ${ }^{4}$, and Suzanne Enzian Knight ${ }^{5}$
}

The differences between rural low-income mothers who were participants and non-participants in the Earned Income Tax Credit (EITC) were examined. One-third of the 224 eligible mothers in a multi-state study did not claim the tax credit. Non-participants were more likely to be Hispanic, less educated, with larger families, borrowing money from family, and living in more rural counties. Participating mothers, on the other hand, were more food secure, perceived their household income as being adequate, reported recent improvements in their economic situation, were satisfied with life, and lived in states with a state EITC. Analysis of qualitative data revealed that rural mothers had many misconceptions about the EITC. These findings contribute to family and economic professionals' understanding of why rural low-income families do not participate in the tax credit and assist in formulating policies and education/outreach efforts that would increase their participation.

Keywords: EITC non-participants, EITC participants, rural low-income mothers, state EITC, rural lowincome families

JEL Classification: I38, J16, J18

\footnotetext{
${ }^{1}$ Sheila Mammen, Department of Resource Economics

University of Massachusetts, 303 Stockbridge Hall

80 Campus Center Way, Amherst, MA 01003-9246

E: smammen@resecon.umass.edu P: 413-545-2470 F: 413-545-5853

${ }^{2}$ Frances C. Lawrence, School of Human Ecology

Louisiana State University, Baton Rouge, LA 70803

E: flawrence@lsu.edu P: 225-578-1726

${ }^{3}$ Peter St. Marie, Department of Resource Economics

University of Massachusetts, 303 Stockbridge Hall

80 Campus Center Way, Amherst, MA 01003-9246

E: pstmarie@student.umass.edu

${ }^{4}$ Ann A. Berry, University of Tennessee

218 Morgan Hall, Knoxville, TN 37996

E: aaberry@utk.edu P: 865-974-8198

${ }^{5}$ Suzanne Enzian Knight, Family Resource Management

University of New Hampshire, 308 Pettee Hall, Durham, NH 03824

E: suzann.knight@unh.edu P: 603-862-0092
} 
The Earned Income Tax Credit and Rural Families: Differences between Participants and Non-participants

Sheila Mammen, Frances Lawrence, Peter St. Marie, Ann Berry, Suzanne Knight 


\title{
The Earned Income Tax Credit and Rural Families: Differences between Participants and Non-participants
}

\begin{abstract}
The differences between rural low-income mothers who were participants and nonparticipants in the Earned Income Tax Credit (EITC) were examined. One-third of the 224 eligible mothers in a multi-state study did not claim the tax credit. Non-participants were more likely to be Hispanic, less educated, with larger families, borrowing money from family, and living in more rural counties. Participating mothers, on the other hand, were more food secure, perceived their household income as being adequate, reported recent improvements in their economic situation, were satisfied with life, and lived in states with a state EITC. Analysis of qualitative data revealed that rural mothers had many misconceptions about the EITC. These findings contribute to family and economic professionals’ understanding of why rural lowincome families do not participate in the tax credit and assist in formulating policies and education/outreach efforts that would increase their participation.
\end{abstract}

Keywords: EITC non-participants, EITC participants, rural low-income mothers, state EITC, rural low-income families 


\section{Introduction}

The labor force fails to lift all low-income families out of poverty (Bok \& Simmons, 2002); some remain poor despite the employment effort of one or even two parents. In order to supplement the household wages of such families and to offset their Social Security taxes, the refundable federal Earned Income Tax Credit (EITC) was initiated in 1975. After numerous expansions the tax credit is now the largest federal assistance program targeted towards working poor families (Wancheck, 2008). As long as the income and citizenship eligibility is met, households with single and married ${ }^{1}$ individuals, with or without children ${ }^{2}$, qualify for the tax credit.

One distinct advantage of the EITC is the bipartisan support that it has garnered in the Congress. There are numerous reasons for this support. First, the EITC requires earnings, i.e., the recipients must have been employed during the previous year in order to qualify. In addition, the EITC appears to be a continued incentive for them to remain in the labor force (Mammen, Lass \& Seiling, in press). Another salient feature of the tax credit is its ability to reduce income inequality. Across the U.S., the EITC transferred over $\$ 43$ billion to 22 million working families in 2006 (Internal Revenue Service, n.d.), and it has been credited for reducing child poverty more than any other federal assistance program (Johnson, Llobrera \& Zahradnik, 2003). In fact, in 1996, when compared to all other government assistance programs, it was the EITC which was credited with lifting almost half of all Hispanic children out of poverty. Similarly in the South, the EITC was credited for moving close to half of all children out of poverty (Greenstein \& Shapiro, 1998). The EITC has also become a major source of additional income for working

\footnotetext{
${ }^{1}$ Married couples cannot file separately.

${ }^{2}$ To be considered a "qualifying child" under EITC, the child must meet 3 eligibility tests dealing with relationship, age, and residency. Moreover, only 1 person can treat the child as a qualifying child and claim the EITC (IRS, 2006).
} 
rural families, especially in the South where there is a larger concentration of rural poor (Economic Research Service [ERS], 1996). Previous research has reported that the tax credit provided many immediate as well as longer term benefits to rural families; it was used to cover bills and loans, provide access to transportation, accumulate assets, purchase a variety of consumer durables and non-durables, improve human capital and, in some cases, to pursue modest leisure activities (Mammen \& Lawrence, 2006).

Assuming that rural low-income families behave in a rational manner as homo economicus, one would expect that they would capitalize on those avenues which would enable them to attain the highest possible well-being for themselves. In spite of the various benefits that working rural families appear to receive from the EITC, many of them miss out on the credit. The opportunity cost of not participating ${ }^{3}$ in the tax credit could be especially significant for low-income rural families because, historically, they have experienced a higher and more persistent poverty rate and lower incomes than urban families (ERS, 1996). Nonetheless, a number of eligible rural households forfeit this income supplement. Such non-participation in the credit is also a costly loss for rural communities as they are deprived of the ripple effects of the EITC revenues that may have otherwise been spent locally. The EITC has, indeed, been considered to be far more effective in stimulating the economy than federal income taxes (Edwards, 2004).

This research focused on the differences between eligible rural low-income mothers who participate and those who do not participate in the EITC. We used both quantitative and qualitative data to address the following questions: a) What misconceptions do rural working low-income mothers have about the EITC? b) How do non-participating rural mothers differ

\footnotetext{
${ }^{3}$ Regardless of whether or not the rural families receive the EITC, the term "participates/do not participate" and any of its derivations is used only in the case of those families who are eligible for the tax credit.
} 
from participating mothers in terms of individual characteristics, material deprivation, and subjective measures? and c) How do macro issues, such as the availability of the state EITC and the relative rurality of the county, affect rural mothers' participation in the federal EITC? The results of this study will contribute to our understanding of why some rural low-income families do not participate in the EITC and may enable policymakers to formulate policies that would increase their EITC participation.

\section{Background and Literature Review}

The federal EITC is the most important credit for low-income working families because of its size and refundable nature. It enables taxpayers, regardless of income tax liability, to receive the full amount of the credit for which they qualify (Berube, 2005). The positive consequences of the federal EITC have prompted several states to enact a state EITC, and in many of these states, the credit is a refundable credit. Together, the federal and state EITC, have lifted many more families out of poverty (Johnson et al., 2003). Neumark and Wascher (2001) concluded that the state EITC and the minimum wage were the two reasons why families were moved out of poverty; the state EITC, however, was the more beneficial of the two, serving as an incentive for previously non-working adults to enter the labor force. A closer examination by the National Center for Children in Poverty (2001) concluded that the state EITC can reduce child poverty but only if it is refundable; in fact, a non-refundable state EITC appears to do little to support children from poor households. Unfortunately, given the current economic difficulties, it is conceivable that states may be faced with declining general revenues and increasing costs. Some 
of them, despite increasing unemployment and declining wages among families, may feel increasing pressure to cut state spending and, as a result, may suspend the state EITC much like Colorado did in 2001 (Johnson et al., 2003).

While families in large cities are the most likely to receive the EITC, they are closely followed by families in rural areas (Berube \& Tiffany, 2004). Analyzing data from the National Longitudinal Survey of Youth, Caputo (2006) reported that about half of the EITC eligible tax filers did not file tax returns. Compared to the non-filers, EITC filers were more likely to be younger, females, less educated mothers, born in the U.S., separated/divorced/widowed, past recipients of Food Stamps and/or TANF, live in poor families for a greater number of years, and work fewer weeks per year on average. On the other hand, non-EITC tax filers tended to be married, White, Northeast residents, and self-employed or in family businesses.

According to Berube and Forman (2001), although a larger percentage of eligible families claimed the EITC compared to more conventional assistance programs such as TANF or Food Stamps, there were still many eligible households that did not file and claim the tax credit. Such non-participants were more likely to have very low incomes, be former welfare recipients, and have language barriers. Additionally, many eligible households, especially low-income Hispanic households, had very little understanding of the EITC.

Phillips (2001a) emphasized the importance of knowledge of the EITC among eligible households. Many poor working households may not file a tax return since their low income exempts them from having to pay income taxes. However, unless these households file an income tax return, they cannot receive the tax credit. On the other hand, even if these households do file a return, they may not receive the tax credit if they fail to claim the EITC on their return. Using data from the 1999 National Survey of American’s Families, Phillips (2001a) highlighted 
many characteristics of those who did not participate in the EITC due to a lack of knowledge about it. Hispanic parents were found to have less knowledge than both low-income white and black non-Hispanic parents. Interestingly, even if they were knowledgeable, the Hispanic parents were less likely to receive the credit. Additionally, married low-income parents had less knowledge and were less likely to receive the credit compared to divorced, separated, and never married parents. Education seemed to matter among the participants; those who had some college education were far more likely to possess knowledge and receive the EITC. Parents who had previously received welfare assistance (AFDC/TANF and Food Stamps) were more knowledgeable than those who had not. Parents who lived in those states with a state EITC were not any more knowledgeable or more likely to receive the federal EITC than those who resided in states without a state EITC.

Phillips (2001b) also noted that parents' country of origin and citizenship played a role in the receipt of the EITC. Those born in the United States were more likely to have received the tax credit followed by those who were naturalized U.S. citizens while low-income immigrants who were not citizens were the least likely to know about it. Phillips (2001b) wondered if difficulties with the English language posed a problem for some poor Hispanic families who, regardless of citizenship status, seemed to know less about the tax credit and, therefore, were less likely to receive it.

Maag (2005) confirmed the conclusion of Phillips (2001a) and others that while the majority (58\%) of low-income parents had some knowledge about the EITC, a significantly smaller proportion (27\%) of low-income Hispanic parents was knowledgeable about the tax credit. Using data from the 2002 National Survey of America’s Families, Maag (2005) also reported that the educational level of the parents played an important role in who knew about the 
tax credit; those parents who did not graduate from high school had significantly less knowledge than those who were college graduates.

A much earlier study (Scholz, 1994) that analyzed data from the 1990 Survey of Income and Program Participation (SIPP) found an EITC participation rate between $80 \%$ and $86 \%$ among taxpayers. Those who received the tax credit were more likely to report higher income, receive a larger EITC payment, and live in states with state income taxes. Non-participants included those who received income from social security and public assistance, had a larger family, were single, were male, and were of Spanish origin (Scholz, 1994).

Using the same data set used in the current study, Varcoe, Lees and Lopez, (2004) examined the EITC participation among rural Latino families in California. They found that only $36 \%$ of those eligible received the tax credit while between $58 \%$ and $64 \%$ did not participate. Some of the non-participating families appeared to possess insufficient or inaccurate understanding of the tax credit or were unaware of its existence. In addition, their inability to find assistance with tax preparation was another barrier that was cited by these Latino families. Similarly, the unavailability of free tax preparation services coupled with a lack of information were cited as reasons for the low participation in the EITC among low and moderate income workers in New Hampshire (Wichroski \& Knight, 2006).

In another study of low-income California households in the 1990s, Hill, Hotz, Mullin and Scholz (1999) concluded that between $42 \%$ and $84 \%$ of eligible households filed a tax return and claimed the tax credit, a rate lower than national estimates. The households that claimed the EITC were more likely to have utilized a paid tax preparer than were households that did not claim the credit. The returns prepared by commercial tax preparers were more likely to be filed electronically and households had a shorter waiting time to receive the tax credit (Hill et al., 
1999). Kopczuk and Pop-Eleches (2007) noted that the commercial tax preparation industry had emphasized electronic filing among low-income neighborhoods, and this had resulted in an increase in the EITC participation. Berube, Kim, Forman and Burns (2002) found that two-thirds (68\%) of the EITC recipients relied on professional assistance with tax filing. They further reported that Hispanic families were more likely to seek external assistance with tax preparation probably because they were less likely to be knowledgeable about the income supplement.

More than $60 \%$ of all the EITC participants in a study by Blumenthal, Erard and Ho (2005) used outside assistance, both paid and unpaid, to file their tax returns. The authors noted that households that were eligible for the EITC were more likely to file their tax returns. Additionally, the larger the tax credit, the more likely it was that households filed a return and claimed the credit. Previous participants were more likely to file while eligible self-employed households were less likely to do so. Finally, according to Blumenthal et al. (2005), tax preparation assistance did not appear to improve an eligible filer's likelihood that he or she would claim the credit.

Maag (2005) noted that of the two-thirds (67\%) of low-income parents who sought help from professional tax preparers, a significant proportion of them were either Hispanic or black, non-Hispanic parents. While external assistance may be considered an advantage, there are also a few distinct drawbacks to using commercial tax preparers. First, the fee charged diminishes the value of the EITC, even more so if the Rapid Anticipation Loan is requested (Berube et al., 2002). Previous studies (Mammen \& Lawrence, 2006; O’Hare \& Johnson, 2004) have found that many rural families use commercial tax preparers who often charge excessive fees which results in an erosion of the value of the EITC benefit. Secondly, when some low-income households rely on professional preparers, they may not consider it necessary to have personal knowledge of 
the tax credit since they are paying for outside expertise. Finally, although one assumes that paid tax preparers would know more about the tax benefits available to their clients, this has not always been the case. According to the Government Accounting Office (2003), some eligible families who used commercial tax preparers did not claim the EITC. Maag (2005), however, argued that while commercial tax preparers did not increase participants' knowledge of the EITC, among those who are knowledgeable about it, the use of paid preparers was associated with a greater receipt of the tax credit.

Our hypotheses, drawn from the literature review, were based on the individual characteristics of the rural low-income working mothers (micro issues) as well as on the characteristics of the county and state in which they reside (macro conditions):

H1: Rural mothers who do not participate in the EITC have less human capital (lower education levels and little understanding of the EITC program).

H2: Rural mothers who do not participate in the EITC are more likely to be older, Hispanic, married, economically marginalized (lower household income, received TANF and Food Stamps), and have more children.

H3: Rural families who do not participate in the EITC face more material deprivation (higher food insecurity, having to borrow money from family/friends and greater material hardship) and are less content with subjective indicators (income adequacy, current economic situation, and satisfaction with life).

H4: Rural families who do not participate in the EITC live in counties that are relatively more rural (Index of Relative Rurality) and in states without a state EITC and a refundable state EITC. 


\section{Data and Methods}

Data for this research came from the USDA-funded multi-state longitudinal project, NC223/NC1011, "Rural Low-Income Families: Tracking Their Well-Being and Functioning in the Context of Welfare Reform.”4 Data collected between August 2000 and July 2001 were used in the current study. The sample consisted of 224 rural low-income families from 23 counties in 13 states, representing every region of the country: California, Indiana, Kentucky, Louisiana, Massachusetts, Maryland, Michigan, Minnesota, Nebraska, New Hampshire, New York, Ohio, and Oregon. To be eligible for the study, families had to have annual incomes at or below 200\% of the Federal poverty line and at least one child under the age of 13 years. Within each rural county, families were chosen to represent the diversity in the types of families with children who were considered low-income, with Hispanic mothers being over sampled. The mothers were recruited through programs that serve low-income families such as the Food Stamp Program, food pantries, housing authority programs, and welfare-to-work programs. Although the purposive sampling limits the ability to generalize the results, since the families represented states in all regions and were recruited broadly from a variety of agencies, the findings of this study will provide important insight on the differences in EITC participation of rural families. In-depth qualitative and quantitative data were collected by trained interviewers during face-to-face interviews with mothers at a site of their choice. The semi-structured protocol included questions on several dimensions including socio-demographics, employment, and on both objective as well as subjective measures of income. Whenever necessary, interviews were conducted in Spanish.

\footnotetext{
${ }^{4}$ For the complete project description, see (Bauer, 2004, pp. 1-4) and http://fsos.cehd.umn.edu/projects/rfs.html.
} 
There are many challenges in studying the EITC such as the difficulty in accurately determining participation as well as compliance and noncompliance (Scholz, 1994; Edwards, 2004). We faced some of the same issues with our data base. The rural respondents were asked if they received the EITC and, if so, how much. However, since their tax return was not checked, we could not be completely certain of whether or not they received the EITC. Furthermore, the amount of data elicited from the respondents varied since the degree of detail in their responses depended entirely upon follow-up questions from the interviewers. To overcome these challenges and to be as precise as possible, with the least amount of bias, we used a series of steps to determine eligibility and participation in the EITC program.

First, we considered the previous year's employment status of the respondent and, wherever applicable, her husband's. Secondly, we checked the previous year's household income, in relation to the number of children, to determine if the family qualified for the EITC. Next, we examined the qualitative responses systematically to verify if the respondent filed taxes, claimed the tax credit, and received the EITC. Finally, we used the size of the reported refunds, as yet another indication, to determine if the EITC was received. In spite of its limitations, the study has several strengths including the uniqueness of our rural sample, the mixed-methods approach, and the inclusion of variables not used elsewhere. Additionally, the current study contributes to the expanding literature on the EITC participation among rural families; after all, it is in the best interest of rural communities to have full EITC participation since the ripple effect of its benefits on the local economies is substantial.

Sample Description 
The sample consisted of 224 rural low-income mothers who were eligible for the EITC; about one-third of the mothers (35\%) did not participate in the EITC while 65\% received the tax credit. As summarized in Table 1, the differences between participants and non-participants were assessed by examining a number of socio-demographic variables.

There was not a significant difference in median age between non-participating mothers (30 years) and participating mothers (29 years). Among the non-participants, there was an almost equal proportion of white non-Hispanic mothers (44\%) as there were Hispanic mothers (46\%). Among those participating in the EITC, however, the overwhelming majority of the participants were white non-Hispanic (73\%) as compared to only $14 \%$ among Hispanics. The much smaller percentage for African-Americans in both cases (non-participants: 5\%; participants: 7\%) is due to the uniqueness of our sample.

Regardless of their EITC participation status, the majority of the mothers were married or living with a partner (non-participants: 79\%; participants: 64\%). Interestingly, single mothers were twice as likely to be participants (22\%) than non-participants (9\%). There was a significant difference in the educational levels of the two groups of rural mothers; when compared to the non-participating mothers (54\%), a far greater proportion of the participating mothers (86\%) had completed high school. Two-thirds of the participating mothers (62\%) had only one or two children while the majority of non-participating mothers (53\%) had three or more children.

One of the criteria for the EITC eligibility is employment, of either the individual or the spouse, in the previous year. Among our sample of rural low-income mothers, a smaller proportion of the EITC non-filers (66\%) worked in the previous year when compared to the filers (72\%). When the previous year's employment status of the spouses/partners was examined, it was interesting to note that the overwhelming majority of the spouses in both groups worked 
(non-participating: 94\%; participating: 92\%). In regards to current employment, nonparticipating mothers (53\%) were far less likely to be currently employed than participating mothers (74\%). The spouses/partners of non-participating mothers were slightly more likely to be currently working than those of the participating mothers (non-participant: 93\%; participant: 89\%). Although not statistically significant, the median income among the mothers who did not receive the tax credit was higher than among those who received the tax credit (non-participants: \$1,949; participants: \$1,840).

\section{Results}

About 35\% of the eligible rural mothers in our sample did not receive the EITC. One of our objectives was to ascertain why these low-income mothers did not participate in the tax credit. Previous studies have established that knowledge of the EITC is a prerequisite to participation. In order to assess rural low-income mothers' knowledge of the tax credit, we examined the qualitative data to identify any misconceptions that these rural mothers, regardless of their EITC participation, might have had about the EITC.

Rural Low-Income Mothers’ Misconceptions about the EITC

Respondents were asked, "Did you receive the Earned Income Tax Credit since our last interview (conducted a year ago). If so, how much?” Both single-parent as well as two-parent families with qualifying children are eligible for the EITC. Furthermore, families are entitled to 
receive the EITC, regardless of whether one or both parents work, so long as the family's income does not exceed the EITC limit. However, there were qualified families in our sample who did not realize that they were eligible, as evident in these cases from California, New Hampshire, and New York respectively:

No, we didn't qualify, oh, did we qualify? I don't know if we qualified for that?

I don't know. No, I don't think we did. Maybe we did. I don't know. Did we get the...no, we didn't. I think we have to be both 21 or even over 21 it said.

No, I don't think we got that because we didn't make quite enough or somethin'. I don't know how that worked. I don't think we did though.

There was an interesting range of recognition and level of awareness of the EITC among the rural mothers. Some recognized it immediately, some could not distinguish it from their regular tax refund or child tax credit, and yet others had little knowledge or understanding of it. Several of them sought explanation about the credit from the interviewers, like these mothers from Minnesota and Nebraska, both of whom were eligible for the tax credit:

What is that?

Would that be figured in your income tax? ...I guess. I don't know. Is that an option for who - what kind of people?

One Massachusetts mother, in response to whether she received the EITC, replied:

I don't do credit cards.

Others simply admitted that they "had no clue” or they “don’t know.” This Indiana mother’s lack of understanding of the credit, however, did not seem to deter her from its benefits:

I have no clue, but I know I get it.

On the other hand, an Ohio mother's lack of knowledge was compounded by the fact that she was disassociated from filing her taxes and, instead, relied on her mother:

No, I, I'm, not sure how much, my mum did my income tax. 
Although the rural respondents were not asked specifically if they used an outside tax preparer, many volunteered the information that they did. It appeared from several of the responses that, as a consequence of relying completely on their tax preparers, they may have paid little attention to their tax return. One such example is illustrated above. Other examples include these mothers from California and Nebraska who when asked if the check that they received from the federal government included the EITC, they replied, respectively:

I don't do the taxes, so I don't know (if the EITC is received).

Yeah, we get that (EITC). Um, our accountant just sent our taxes back a couple of weeks ago to us, and, yeah, we get that. I can't remember how much, but...

In response to a question on the kind of tax refund that she was expecting, an Indiana mother simply added,

A rapid is all I know.

Finally, we found evidence of what may be considered irrational consumer behavior among some rural mothers who were not acting in their best economic interest. They did not claim the EITC, even though an examination of their eligibility status indicated that they were clearly qualified. These low-income families from Massachusetts, New York, and Oregon did not receive the tax credit simply because they failed to file their taxes, sometimes for inexplicable reasons:

Why open a can of worms? I only worked three months, ten hours a week. They can keep it...

No I used to (do taxes), but, now that I'm married it's too complicated (laughs) for me.

I have not done my taxes for two years. But we qualify (for the EITC)...

There was at least one instance where a lack of assistance with tax preparation prevented a Massachusetts mother from filing her taxes. She told the interviewer, plaintively: 
I haven't filed taxes in years. I need help with that.

In order to understand why qualified rural low-income mothers would fail to claim the income supplement, the differences between those eligible mothers who received and those who did not receive the EITC were analyzed using several elements: individual characteristics, variables that expressed the material deprivation experienced by the family, and, finally, responses to a series of subjective indicators that measured financial well-being and overall well-being. The Pearson chi-square statistic and difference of mean tests were used for the bivariate analyses that tested for associations between the EITC participation status and the various independent variables.

Differences between the EITC Non-Participating and Participating Mothers: Individual Characteristics, Material Deprivation, and Subjective Measures

Individual characteristics of the respondents included education and knowledge of the EITC, age, ethnicity, marital status, number of children, household income, and past receipt of TANF and food stamps. As seen in Table 2, education was important to the EITC participation. Among the non-participants, the majority of them (46\%) did not have a high school degree or its equivalent while $86 \%$ of the participating mothers had, at a minimum, completed high school. The qualitative responses of the mothers were used to clarify whether or not they were knowledgeable about the tax credit. Having some knowledge of the EITC was strongly correlated with receiving it. Of those who had no knowledge of the EITC, about half of them 
received the tax credit ${ }^{5}$ while among those who did have some knowledge, a much higher percentage (84\%) received it $\left(\chi^{2}: 17.4 ; \mathrm{p}: 0.000\right)$.

Rural mothers who did not receive the tax credit were more likely to be under 30 years of age. However, this was not statistically significant. Hispanics were far less likely to receive the EITC than either white or black non-Hispanics; only 36\% of Hispanics received the credit. Among whites, about $76 \%$ of the families received the EITC while the participation rate for blacks was only slightly lower at $71 \%$. The majority of the rural mothers in the sample were married; among them, about 60\% were EITC recipients. Similarly, two-thirds of the mothers who were divorced, separated or widowed were recipients. On the other hand, an overwhelming majority of single mothers (82\%) received the EITC. Families who did not participate were slightly more likely (53\%) to have 3 or more children than those families who had 1 or 2 children $(47 \%)\left(\chi^{2}: 4.8 ; \mathrm{p}: 0.028\right)$.

To assess if economically marginalized respondents were more or less likely to receive the EITC, respondents’ income and their previous receipt of TANF and food stamps were examined. The likelihood of receiving the EITC was not affected by whether or not families were above or below the median family income of our sample. Similarly, their past receipt of TANF and/or food stamps was not related to participation in the EITC.

Three variables were used to assess if material deprivation was a factor in whether or not rural low-income mothers received the EITC: food insecurity, borrowing money from family/friends, and material hardship. Food security may be defined as families’ consistent and dependable access to sufficient food to maintain an active and healthy life (Nord, Andrews \& Carlson, 2005). Families are considered food insecure when safe and nutritionally adequate food

\footnotetext{
${ }^{5}$ We base this on two points: (a) these families were eligible for the EITC and (b) the size of their refund suggests that they received the tax credit.
} 
is either not readily available or when they have to resort to extraordinary means to obtain it. Of the families who received the EITC, more were food secure (65\%) than food insecure (36\%); $73 \%$ of the food secure families received the EITC while only $57 \%$ of the food insecure families received the EITC ( $\left.\chi^{2}: 6.344 ; \mathrm{p}: 0.012\right)$ (see Table 3). Among the non-participants, $65 \%$ of them needed to borrow money from family and/or friends, whereas $56 \%$ of the participants needed to do the same thing. The degree to which these rural families experienced material hardship was assessed with a hardship index which was constructed using responses to the question, "In the past year, has there been a time when you had a hard time making ends meet or paying for necessities? Did you have trouble paying for (coded yes or no): (a) food (b) clothing (c) medical care (d) dental care (e) medicines and (f) other.” The mean hardship index for families who participated in the EITC was not statistically different than that for those who did not (t: 0.642).

A variety of subjective indicators were used to assess the differences between the EITC participants and non-participants. These included income adequacy, perception of current economic situation, and satisfaction with life. The adequacy of respondents' income was gauged with the question, “To what extent do you think your income is enough for you to live on?” Respondents selected a response from: (a) not at all (b) can meet necessities only (c) can afford some of the things we want but not all we want (d) can afford about everything we want (e) can afford about everything we want and still save money. Of families receiving the EITC, fewer felt that their income was inadequate (25\%) and more felt that their income was adequate (57\%) or more than adequate (19\%) when compared to those who did not receive the EITC (38\%, 48\%, and $14 \%$ respectively) ( $\chi^{2}: 4.347 ;$ p:0.114) (see Table 4).

The mothers were asked if there had been a change in their financial situation, “Compared to two years ago, would you say your family's economic situation has: (a) improved 
a lot (b) improved a little (c) remained the same (d) gone down a little (e) gone down a lot.” A larger proportion of mothers who felt that their economic situation had improved from two years ago received the EITC (70\%) compared to those mothers who had not received the EITC (30\%). Low-income rural mothers' satisfaction with life was ascertained by asking, "Overall, how satisfied are you with your life right now?” Respondents selected from: (a) very dissatisfied, (b) dissatisfied, (c) mixed feelings, (d) satisfied, or (e) very satisfied. A larger proportion of respondents who received the EITC were very satisfied with their life (74\%) than those who did not receive the EITC (56\%) $\left(\chi^{2}: 7.50 ; \mathrm{p}: 0.022\right)$.

Differences between the EITC Non-Participating and Participating Mothers: Relative Rurality of the County and Availability of the State EITC

By design, this study focused on low-income rural families; therefore, all the respondents in the study lived in rural counties across the country. Rural counties, however, are not exactly alike in terms of how "rural” they are; they may vary by population size and density, distance from urban centers, access to a variety of services, etc. Although defining and measuring rurality often poses challenges, it is useful to do so because where one resides may influence one's behavior. The Index of Relative Rurality (IRR), a continuous, multidimensional measure of a county's degree of rurality, incorporates four dimensions including population size, population density, extent of area that is urbanized, and the distance to the nearest metropolitan area (Waldorf, 2007). The IRR is scaled from 0 to 1 , with 0 representing the place that is the most urban and 1 representing the place that is the most rural. The mean for the IRR was higher (t: 0.049) for families who did not receive the EITC. 
Several states implemented a state EITC following the success of the federal EITC. In the case of some of these states, the tax credit is refundable as is true of the federal tax credit as well. The states in the data set that had a state EITC in 2001 were Maryland, Massachusetts, Minnesota, New York, and Oregon (Johnson et al., 2003). Almost 74\% of families residing in states without the state EITC received the tax credit. Interestingly, in those states with the state EITC, there was little difference in the percentage between those who received the income supplement (53\%) and those who did not (47\%) (Table 5). Among families who did receive the EITC, 65\% lived in states without the state EITC whereas 35\% lived in states with the state tax credit.

Of the states that had a state EITC in our dataset, Oregon was the only state whose tax credit was not refundable. The refundable state EITC is considered to provide working families with greater financial benefits. However, when we compared the respondents who lived in a state that provided a refundable state EITC to those who lived in a state without such a tax credit, we did not find a statistically significant difference between the percentage of families who received the tax credit and those who did not.

\section{Discussion}

One-third of eligible rural low-income mothers in our sample did not file and claim the EITC. Other studies have reported non-participation rates that have ranged from $16 \%$ to $64 \%$ (Hills et

al., 1999; Scholz, 1994; Varcoe, 2004). Through the analyses of both quantitative and qualitative data, the current study has revealed many characteristics about the mothers who did not 
participate in the tax credit. To some extent, these findings corroborate those from other studies on the EITC participation. As has been pointed out previously (Caputo, 2006; Phillips, 2001a), first and foremost, knowledge of the EITC is crucial to whether or not eligible households receive the tax credit; these households must be aware of the program, have some understanding or knowledge of the program, file their taxes and, finally, claim the tax credit in order to receive it. For this reason, our first objective was to gauge rural low-income mothers' knowledge level of the EITC by highlighting their misconceptions about it.

A methodical examination of the qualitative responses from all rural mothers in the sample indicated that there were many misconceptions about the tax credit. Regardless of whether or not they received the EITC, many respondents had little or no knowledge about the tax credit; some appeared totally clueless, and others were completely misinformed about its eligibility criteria. Among those who did not receive it, several failed to claim the credit because they did not realize that they qualified for it, for example, when there was a change in their marital status or because they did not work very much and, therefore, did not have to file a tax return. On the other hand, there were respondents who recognized the EITC right away, appeared to have some knowledge of it, and were able to specify the amount that they received. For others, the fact that they received the tax credit was evident from their responses; however, they confused it with their regular tax refund or their child credit.

As noted in previous studies (Berube et al., 2002; Blumenthal et al., 2005; Maag, 2005; O’Hare \& Johnson, 2004), the EITC participants often seek tax assistance from paid as well as unpaid preparers. We surmised from their responses that many rural families sought outside assistance with tax filing perhaps due to their lack of understanding or confidence to fill out a tax return and get it filed. As illustrated by the quotes in the results section, the respondents' 
confusion about the tax credit may, partly, be due to the fact that when they use paid or unpaid tax preparers, they seem to "hand over" the burden of filing the return to these preparers. Such reliance on outside assistance appears to discharge the mothers from understanding the EITC or adding to their knowledge about it, as previously suggested by Maag (2005).

Surprisingly, there were a few low-income rural mothers who did not file their taxes and claim the tax credit for reasons that seemed to defy logic. This may also be considered a misconception on their part as their lack of understanding of the credit prevented them from benefitting from it. Finally, as was also recognized by Varcoe et al. (2004), it was clear that for some low-income households a lack of outside assistance with tax returns prevented them from claiming the EITC.

The second objective of the current study was to assess how rural mothers who did not participate in the EITC differed from those mothers who did. To do this, we considered several of their individual characteristics, the material deprivation that they experienced, and a number of subjective measures that described their well-being. Our results, similar to those of Caputo (2006), Maag (2005), and Phillips (2001), showed that education made a difference in mothers' EITC participation; those with higher levels of education were more likely to participate. This was also the case with knowledge of the EITC; mothers with some knowledge were more likely than those without knowledge to participate in the tax credit supporting the results of Berube and Foreman (2001), Maag (2005), Phillips (2001a), and Varcoe (2004). This finding points to the importance of having adequate knowledge and understanding of the tax credit in order for qualified families to claim it. Without awareness of the existence of the income supplement, economically vulnerable families, for whom this program is intended, simply cannot take advantage of it. 
Rural mothers who were under the age of 30 were less likely to claim the EITC. This, however, contradicted Caputo’s (2006) finding that younger parents were more likely to receive the tax credit. Almost all other studies (Berube \& Foreman, 2001; Caputo, 2006; Maag, 2005; Phillips, 2001a; Varcoe, 2004) have concluded that there is a strong relationship between ethnicity and participation in the EITC. Our study was no exception; we found that Hispanic families, by a substantial margin, were the least likely to receive the EITC. Phillips (2001b) noted that U.S. citizenship, through being native born or naturalized, is an important factor in determining one's knowledge and subsequent receipt of the EITC. We did not inquire about respondents' citizenship status ${ }^{6}$. However, it was clear that there was a variation among the Hispanic families; many of them, having lived in the U.S. for a long time, would be considered "settled" families while others arrived more recently or were migrant families. It is conceivable that some of those Hispanic rural mothers who had a limited facility with the English language found that this posed a barrier. In this aspect, we concur with Phillips (2001b), who cited language difficulties as another obstacle in the EITC participation.

The vast majority of the mothers were married or partnered in our sample. Caputo (2006) and Phillips (2001a) reported that non-EITC filers were more likely to be married. Our results indicated that while more married mothers were filers than non-filers, they did not participate at the same rate as divorced/separated/widowed women and, especially, single women who were far more likely to participate in the tax credit. Although counterintuitive, non-participants had larger families (3 or more children), a point that was also observed by Scholz (1994). This might be a reflection of the fact that a larger EITC benefit tier has not been established for families with

\footnotetext{
${ }^{6}$ In order to be able to claim the EITC, respondents must be a U.S. citizen (native born or naturalized) or a resident alien all year or a nonresident alien married to a US citizen.
} 
3 or more children, in spite of the greater financial needs that such families have (Greenstein, 2000).

Several studies (Berube \& Foreman, 2001; Scholz, 2001) have found a relationship between non-participation in the EITC and those who have very low income and/or received welfare assistance in the recent past. We did not find this to be the case in our study; neither household income nor receipt of TANF and/or Food Stamps made any difference in whether or not rural mothers participated in the tax credit. Although mothers who were economically marginalized were expected to be less likely to take advantage of the income supplement, it is possible that because the income distribution between participants and non-participants was so similar, it did not contribute to the differences in their participation.

Three variables used to indicate material deprivation included food security status, whether or not the respondents turned to their family/friends to borrow money, and the extent of material hardship experienced. Berube and Foreman (2001) reported that very poor families were more likely to be non-participants, whereas Caputo (2006) found the opposite to be the case. We found that the EITC filers were more likely to be food secure. At the same time, non-participants were more likely to have borrowed money from family and friends. It is possible that some of these families may not have had to borrow if they had the additional income provided by the EITC or, perhaps, if they signed up for the advance EITC. Interestingly, however, there was no difference in the degree of material hardship experienced by participants and non-participants. It is possible to interpret our findings as corroborating that of Berube and Foreman (2001), suggesting that the EITC may be useful in providing some form of financial freedom to those who receive it. 
Using subjective indicators to understand the differences between the EITC filers and non-filers added a unique perspective to this study. The indicators included the adequacy of income, economic situation compared to the recent past, and satisfaction with the quality of life. Compared to the non-participants, the EITC participants perceived their income as being more adequate and their current financial situation as having improved in the past two years. This may be due to several possibilities: the EITC participants may have been on TANF before they were employed, or the household income may have increased because they got a better paying job or got married. Regardless of the reason, the result that such families are more likely to be positive about their income adequacy and current financial situation may be considered an affirmation of their participation in the tax credit. Those who received the EITC were also more likely to be satisfied with their life; this is yet another possible indication of the positive consequence of receiving the tax credit.

Another objective of this study was to examine if rural mothers' participation in the federal EITC would differ in the light of macro conditions such as the relative rurality of the county in which they live as well as the availability of the state EITC, refundable or not. Although all the families lived in rural counties, the degree of rurality was not identical across the counties. For example, some of them in the Midwestern states were extremely remote while other counties in New England were less remote. Our results suggest that families who lived in the more rural counties were less likely to receive the tax credit. One plausible explanation is that outside tax preparation service (whether paid or free) may have been less available in extremely rural counties, and for mothers who were already less knowledgeable about the credit, this probably made it hard for them to file their tax returns and claim the credit. 
Of those who received the EITC, more lived in states that had a state tax credit which contradicts the conclusion reached by Phillips (2001a) that those who lived in states with the EITC were not any more likely to receive the credit. The refundable state EITC is considered to provide working families with greater financial benefits and, therefore, greater incentive to claim the EITC. Our results, however, did not support this; having the refundable state EITC made no difference in participation.

Unlike many other studies that assessed the EITC participation in general, we focused exclusively on the EITC participation of rural low-income mothers. Nonetheless, our results have supported, to a large extent, the general profile of the EITC non-participants created by the other studies. Non-participating rural mothers were more likely to be less educated, Hispanic, and have more children. They were also more likely to have borrowed money from family and friends and to have lived in more rural counties. On the other hand, participating mothers were more likely to be food secure, perceive their household income as being adequate, report on a recent improvement in their economic situation, and be satisfied with their life.

\section{Conclusion and Policy Implications}

There is substantial interest among scholars and policymakers in the differences between the EITC participants and non-participants. Findings from past research have concluded unequivocally that the tax credit provides a powerful boost to the lives of low-wage families in a variety of ways. When the EITC would add appreciably to their financial well-being, why would some of these households forego their economic self-interest in claiming this income 
supplement? Our study contributes to the growing research in this area by highlighting rural lowincome families, a unique group which constitutes a sizeable segment of the rural population. Additionally, our conclusions have been enriched through the use of the mixed-methods approach as well as the inclusion of subjective measures such as the adequacy of income and an assessment of current economic situation. This study on the EITC participation has, therefore, provided an important contribution to our understanding of the economic behavior of working rural families.

An analysis of the qualitative data revealed that rural low-income mothers had many misconceptions about the EITC, which clearly worked to their detriment. Having little or no knowledge or possessing incorrect information exacerbated their inability to claim the tax credit. Even in cases where paid tax preparers or unpaid preparers (family and friends) were used, the respondents would have been better served if they had personal knowledge of the EITC.

Several variables that described their individual characteristics, material deprivation, and subjective measures were associated with low-income rural mothers' participation in the tax credit. Human capital, in terms of education and knowledge of the EITC, made a significant difference in whether or not they claimed the tax credit. This finding supported our hypothesis that rural mothers who did not participate in the EITC were less likely to have a high school education or possess much knowledge of the EITC.

When compared to the non-Hispanic white and black rural low-income mothers in our sample, the Hispanic mothers were the least likely to claim the tax credit. In this way, our findings supported our hypothesis and corroborated that of many other studies that have highlighted the generally lower EITC participation rate among Hispanic families. 
Our results did not support the hypothesis that older rural mothers were less likely to claim the tax credit. Likewise, whether or not respondents were economically marginalized, with lower household income and a recent history of receiving TANF and Food Stamps, did not make any difference in their participation in the EITC. It is quite possible that the uniqueness of our sample may have contributed partly to this finding.

There was no consensus in the literature about the EITC participation rate among very poor families. Using a variety of variables to characterize material deprivation, we hypothesized that non-participating families were more likely to be materially deprived. Our results were decidedly mixed. On one hand, food secure families were more likely to claim the tax credit. On the other hand, those who had to borrow money from family and friends were more likely not to participate. The third variable, the degree of material hardship experienced, made no difference in the EITC participation.

Rural low-income mothers who expressed contentment with subjective indicators, which included income adequacy, current economic situation, and satisfaction with life, were more likely to claim the EITC. This finding supported our hypothesis and is particularly noteworthy because the association between these subjective measures and the EITC participation has not been previously addressed elsewhere.

Finally, we had also hypothesized that those mothers who lived in counties that were relatively more rural and in states without a state EITC and a refundable state EITC were less likely to participate in the federal tax credit. The mothers who lived in more rural counties were indeed less likely to claim the EITC. While those who lived in states with a state EITC were more likely to participate in the federal EITC, living in a state with a refundable state EITC made no difference. 
Without a doubt, the EITC is an additional source of income for economically struggling families. This should, therefore, be an impetus for such families to file their taxes and claim the tax credit. However, one-third of the rural low-income mothers in our study did not claim the EITC and this conforms to the findings of others that indicate not all eligible individuals claim the tax credit. Among our sample of rural mothers, those who did not participate included the more vulnerable such as ethnic minorities, perhaps, burdened by cultural and language barriers, those with far less income, and those who lived in relatively more rural areas. These findings point to the importance of ensuring that low-income families are made aware of the existence and the many benefits of the EITC. One effective way of doing this might be through the federal and state governments partnering with employers to get the word out about the income supplement. Providing a larger EITC to families with 3 or more children may increase their participation in the tax credit simultaneously reducing the poverty rate among this group.

The rural mothers who did not file taxes may have if they had had access to outside tax preparation services. Although paid tax preparers are available, their high fees and the reduced value of the EITC that accompany rapid refunds are disadvantages to using commercial preparers. A viable alternative is the Volunteer Income Tax Assistant (VITA) which is a program, located in communities nationwide, with IRS certified tax preparers who do not charge clients for filing taxes. From a policy point of view, it is important to provide or, if already available, publicize the free tax preparation service offered by local community volunteers through VITA. While paid preparers are financially able to locate their offices and advertise in low-income neighborhoods, free tax preparation sites often have only limited or no marketing budget to do the same. 
Some of the rural mothers did not know that they qualified for the EITC when, for example, there was a change in their life circumstance such as in their marital status. If they had gone to a free tax preparation site or a paid preparer, they would have learned they were eligible unless their marital status went from head of household to married filing jointly and the joint income was above the qualifying EITC income level or they were married filing separately. Free tax preparation services must be marketed more aggressively so that people know that they exist, they are free, and they are helpful. Volunteers in free tax preparation sites are trained to go over clients' tax return with them, which may increase their knowledge of the EITC and clear up any misconceptions.

It is also in the best interest of the economy of rural areas to publicize and encourage working families to claim the EITC; the increased spending potential of low-income families and the consequent multiplier effect is a tremendous boon for the local communities. Yet another policy implication involves the implementation of the EITC in states. By expanding the number of states that provide the state EITC and the refundable state EITC, low-wage families who are the beneficiaries could see additional benefits. 


\section{Acknowledgments}

This research was supported in part by USDA/CSREES/NRICGP Grants - 2001-3540110215, 2002-35401-11591, 2004-35401-14938. Data were collected in conjunction with the cooperative multi state research project NC-223/NC-1011 Rural Low-income families: Tracking Their Well-being and Functioning in the Context of Welfare Reform. Cooperating states are California, Colorado, Indiana, Kentucky, Louisiana,

Massachusetts, Maryland, Michigan, Minnesota, Nebraska, New Hampshire, New York, Ohio, Oregon, and West Virginia. 


\section{References}

Berube, A. (2005). The tax code as social policy in rural America. Rural Poverty Research Center Working Paper no. 05-08. Retrieved December 9, 2008, from http://www.rprconline.org/WorkingPapers/WP0508.pdf

Berube, A., \& Thacher, T. (2004). The "State" of Low-Wage Workers: How the EITC Benefits Urban and Rural Communities in the 50 States. EITC Series. Washington D.C.: Brookings Institution Center on Urban and Metropolitan Policy. Retrieved from http://www.brookings.edu/ /media/Files/rc/reports/2004/02childrenfamilies_berube/2004 0203_berube.pdf.

Berube, A., Kim, A., Forman, B., \& Burns, M. (2002). The Price of Paying Taxes: How Tax Preparation and Refund Loan Fees Erode the Benefits of the EITC. Survey Series. Washington, DC: The Brookings Institution Progressive Policy Institute. Retrieved from http://www.brookings.edu/ES/urban/publications/berubekimeitc.pdf

Berube, A. \& Forman. B. (2001). A local ladder for the working poor: The impact of the earned income tax credit in U.S. metropolitan areas. The Brookings Institution. EITC Series. 116. Retrieved December 9, 2008, from http://www.brookings.edu/reports/2001/10poverty_berube.aspx.

Blumenthal, M., Erard, B., \& Chih-Chin Ho. (2005). Participation and Compliance with the Earned Income Tax Credit. National Tax Journal, 58(2), 189-213.

Bok, M., \& Simmons, L. (2002). Post-Welfare Reform, Low-Income Families and the Dissolution of the Safety Net. Journal of Family and Economic Issues, 23(3), 217-238. doi: 10.1023/A:1020391009561.

Caputo, R. K. (2006). The Earned Income Tax Credit: A Study of Eligible Participants vs. Nonparticipants. Journal of Sociology \& Social Welfare, 33(1), 9-29.

Edwards, R. D. (2004). Macroeconomic implications of the earned income tax credit. National Tax Journal, 57(1), 45-65.

Government Accountability Office (GAO). (2003). Tax Administration: Most Taxpayers Believe They Benefit from Paid Tax Preparers, but Oversight for IRS Is a Challenge. GAO-0470. Washington, DC:GAO. Retrieved 9 December, 2008, from http://www.gao.gov/new.items/d0470.pdf.

Greenstein, R. (2000). Should EITC benefits be enlarged for families with 3 or more children? Center on Budget and Policy Priorities. Retrieved December 9, 2008, from http://www.cbpp.org/3-14-00tax.pdf 
Greenstein, R. \& Shapiro, I. (1998). New research findings on the effects of the Earned Tax Credit. Center on Budget and Policy Priorities. Retrieved December 9, 2008, from http://www.cbpp.org/311eitc.htm

IRS Earned Income Tax Credit Statistics (n.d.). IRS. Retrieved December 9, 2008, from http://www.irs.gov/individuals/article/0,,id=177571,00.html

Johnson, N., Llobrera, J., \& Zahradnik, B. (2003). A hand up: How state earned income tax credits help working families escape poverty in 2003. Center on Budget and Policy Priorities. Retrieved December 9, 2008, from http://www.cbpp.org/3-3-03sfp.htm

Kopczuk, W. \& Pop-Eleches, C. (2007). Electronic filing, tax preparers and participation in the Earned Income Tax Credit. Journal of Public Economics, 91, 1351-1367. doi: 10.1016/j.jpubeco.2006.11.003.

Hill, C., Hotz, J., Mullin, C., \& Scholz, J. (1999). EITC Eligibility, Participation, and Compliance Rates for AFDC Households: Evidence from the California Caseload. Northwestern University/University of Chicago Joint Center for Poverty Research. Retrieved December 9, 2008, from http://ideas.repec.org/p/wop/jopovw/102.html.

Maag, E. (2005). Paying the price? Low-income parents and the use of paid tax preparers. The Urban Institute. New Federalism: National Survey of America's Families B-64. Retrieved December 9, 2008, from http://www.urban.org/UploadedPDF/411145_B-64.pdf

Mammen, S., Lass, D., \& Seiling, S. (in press). Labor Force Supply Decisions of Rural LowIncome Mothers. Journal of Family and Economic Issues.

Mammen, S., \& Lawrence, F. C. (2006). How Rural Working Families Use the Earned Income Tax Credit: A Mixed Methods Analysis. Financial Counseling and Planning, 17(1), 5163.

National Center for Children in Poverty (2001). Untapped potential: State earned income credits and child poverty reduction. Mailman School for Public Health, Columbia University. Research Brief 3. Retrieved December 9, 2008, from http://www.nccp.org/publications/pdf/text_382.pdf

Neumark, D., \& Wascher, W. (2001). Using The EITC to Help Poor Families: New Evidence and a Comparison with the Minimum Wage. National Tax Journal, 54(2), 281-317.

Nord, M., Andrews, M. \& Carlson, S. (2005). Household food security in the United States, 2005. (Economic Research Report No. 29). United States Department of Agriculture, Economic Research Service. Retrieved December 20, 2007, from http://www.ers.usda.gov/Publications/ERR29/

O’Hare, W.P. \& Johnson, K.M. (2004). Child poverty in rural America. Population Reference Bureau, Reports on America. 4:1, 1-19. 
Ross Phillips, K (2001). The earned income tax credit: Knowledge is money. Political Science Quarterly, 116, 413-424.

Ross Phillips, K. (2001). Who knows about the Earned Income Tax Credit? Policy brief. Assessing the New Federalism project. The Urban Institute. 1-7. Retrieved December 9, 2008, from http://www.urban.org/publications/310035.html.

Scholz, J.K. (1994). The earned income tax credit: Participation, compliance, and antipoverty effectiveness. National Tax Journal, 47(1), 63-87.

Varcoe, K.P., Lees, N.B. \& Lopez, M.L. (2004). Rural Latino families in California are missing earned income tax benefits. California Agriculture, 58:1, 24-27. Retrieved December 9, 2008, from http://calag.ucop.edu/0401JFM/pdfs/EIC.pdf

Waldorf, B. (2007). Measuring rurality. In Context. 8:1, 5-8. Retrieved December 9, 2008, from http://www.incontext.indiana.edu/2007/january/2.html

Wancheck, J. (2008) National Low Income Housing Coalition. Earned Income Tax Credit. Retrieved December 9, 2008, from http://www.nlihc.org/detail/article.cfm?article_id=5205\&id=46

Wichroski, M.A. \& Knight, S. (2006). New Hampshire Earned Income Tax Credit Project Employer Survey Results. University of New Hampshire Cooperative Extension. Unpublished manuscript. 
Table 1 Socio-demographic characteristics of mothers by the EITC participation status

\begin{tabular}{|c|c|c|c|c|}
\hline & \multicolumn{2}{|c|}{ Non-Participating $(\mathrm{n}=79)$} & \multicolumn{2}{|c|}{ Participating $(\mathrm{n}=145)$} \\
\hline & $\mathrm{N}$ & $\%^{\mathrm{a}}$ & $\mathrm{n}$ & $\%^{\mathrm{a}}$ \\
\hline \multicolumn{5}{|l|}{ Age } \\
\hline Under 30 & 47 & 59.5 & 78 & 53.8 \\
\hline 30 and above & 32 & 40.5 & 67 & 46.2 \\
\hline Median age (years) & & 30 & & 29 \\
\hline \multicolumn{5}{|l|}{ Ethnicity } \\
\hline White, non-Hispanic & 34 & $43.6 * *$ & 106 & $73.1^{* *}$ \\
\hline Hispanic & 36 & $46.2 * *$ & 20 & $13.8 * *$ \\
\hline African American & 4 & 5.1 & 10 & 6.9 \\
\hline Other & 4 & 5.1 & 9 & 6.2 \\
\hline \multicolumn{5}{|l|}{ Marital status } \\
\hline Married/living with a partner & 62 & $78.5^{*}$ & 92 & $63.9 *$ \\
\hline Divorced/separated & 10 & 12.7 & 20 & 13.9 \\
\hline Single & 7 & $8.9 * *$ & 32 & $22.2 * *$ \\
\hline \multicolumn{5}{|l|}{ Education } \\
\hline Less than high school & 36 & $46.2^{* *}$ & 21 & $14.5^{* *}$ \\
\hline High school & 16 & $20.5^{*}$ & 48 & $33.1^{*}$ \\
\hline More than high school & 26 & $33.3 * *$ & 76 & $52.4 * *$ \\
\hline \multicolumn{5}{|l|}{ Number of children } \\
\hline One or two & 37 & $46.8^{*}$ & 90 & $62.1^{*}$ \\
\hline Three or more & 42 & $53.2^{*}$ & 55 & $37.9 *$ \\
\hline \multicolumn{5}{|c|}{ Previous year working status, mother } \\
\hline Not working & 27 & 34.2 & 41 & 28.3 \\
\hline Working & 52 & 65.8 & 104 & 71.7 \\
\hline \multicolumn{5}{|c|}{ Previous year working status, spouse } \\
\hline Not working & 4 & 6.2 & 7 & 8.5 \\
\hline Working & 61 & 93.8 & 75 & 91.5 \\
\hline \multicolumn{5}{|l|}{ Current working status, mother } \\
\hline Not working & 33 & $47.1 * *$ & 37 & $25.7 * *$ \\
\hline Working & 37 & $52.9 * *$ & 107 & $74.3^{* *}$ \\
\hline \multicolumn{5}{|l|}{ Current working status, spouse } \\
\hline Not working & 4 & 7.5 & 10 & 11.0 \\
\hline Working & 49 & 92.5 & 81 & 89.0 \\
\hline \multicolumn{5}{|l|}{ Monthly income ${ }^{b}$} \\
\hline Less than $\$ 1,000$ & 19 & 24.1 & 27 & 18.6 \\
\hline$\$ 1,000-\$ 1,499$ & 9 & 11.4 & 27 & 18.6 \\
\hline$\$ 1,500-\$ 1,999$ & 13 & 16.5 & 25 & 17.2 \\
\hline$\$ 2,000-\$ 2,499$ & 14 & 17.7 & 25 & 17.2 \\
\hline
\end{tabular}




\begin{tabular}{|c|c|c|c|c|}
\hline More than $\$ 2,500$ & 24 & 30.4 & 41 & 28.3 \\
\hline Median income (\$) & & 1,949 & & 1,840 \\
\hline
\end{tabular}

Note: Asterisks indicate values which are statistically different between non-participants and participants. * $\mathrm{P}<0.05, * * \mathrm{P}<0.01$.

${ }^{\text {a }}$ Percentage of total number of non-participants or participants.

${ }^{\mathrm{b}}$ Monthly and median income are in current dollars at the time of data collection. 
Table 2 Comparison of individual characteristics between the EITC nonparticipating and participating rural mothers

\begin{tabular}{|c|c|c|}
\hline & $\begin{array}{l}\text { Non-Participating } \\
\text { (\%) }\end{array}$ & $\begin{array}{l}\text { Participating } \\
\text { (\%) }\end{array}$ \\
\hline Less than high school education & $46.2_{\mathrm{a}}$ & $14.5 \mathrm{~b}$ \\
\hline High school or GED & $20.5_{a}$ & $33.1_{b}$ \\
\hline More than high school & $33.3_{\mathrm{a}}$ & $52.4_{b}$ \\
\hline Little or no understanding of EITC & $47.5_{a}$ & $15.9_{b}$ \\
\hline At least fair understanding of EITC & $52.5_{a}$ & $84.1_{b}$ \\
\hline Under 30 years old & $59.5 \mathrm{a}$ & $53.8_{a}$ \\
\hline 30 or more years old & $40.5 \mathrm{a}$ & $46.2_{a}$ \\
\hline White, non-Hispanic & $43.6_{a}$ & $73.1_{b}$ \\
\hline Hispanic & $46.2_{\mathrm{a}}$ & $13.8_{b}$ \\
\hline Black & $5.1_{\mathrm{a}}$ & $6.9_{a}$ \\
\hline Other & $5.1_{\mathrm{a}}$ & $6.2_{\mathrm{a}}$ \\
\hline Married/partnered & $78.5 \mathrm{a}$ & $63.9_{b}$ \\
\hline Divorced/separated & $12.7 \mathrm{a}$ & $13.9_{a}$ \\
\hline Single & $8.9_{\mathrm{a}}$ & $22.2_{b}$ \\
\hline Less than three children & $46.8_{\mathrm{a}}$ & $62.1_{\mathrm{a}}$ \\
\hline Three or more children & $53.2_{\mathrm{a}}$ & $37.9 \mathrm{a}$ \\
\hline Income below sample median & $43.0_{a}$ & $47.6 \mathrm{a}$ \\
\hline Income above sample median & $57.0_{a}$ & $52.4_{a}$ \\
\hline Not receiving TANF & $97.5_{a}$ & $93.8_{a}$ \\
\hline Receiving TANF & $2.5_{\mathrm{a}}$ & $6.2_{\mathrm{a}}$ \\
\hline Not receiving food stamps & $69.6_{a}$ & $60.0_{\mathrm{a}}$ \\
\hline Receiving food stamps & $30.4_{a}$ & $40.0_{a}$ \\
\hline
\end{tabular}


Note: Values in the same row that do not share subscripts are statistically different at the 5\% level, between non-participants and participants. 
Table 3 Comparison of measures of material deprivation between the EITC non-participating and participating rural mothers

\begin{tabular}{lcc}
\hline & Non-Participating & Participating \\
\hline Food secure (\%) & $46.5_{\mathrm{a}}$ & $64.5_{\mathrm{b}}$ \\
Food insecure (\%) & $53.5_{\mathrm{a}}$ & $35.5_{\mathrm{b}}$ \\
Did not have to borrow money from relative or friend (\%) & $35.1_{\mathrm{a}}$ & $44.0_{\mathrm{a}}$ \\
Had to borrow money from relative or friend (\%) & $64.9_{\mathrm{a}}$ & $56.0_{\mathrm{a}}$ \\
Index of material hardship $^{\mathrm{c}}$ (mean) & $1.4_{\mathrm{a}}$ & $1.5_{\mathrm{a}}$ \\
\hline
\end{tabular}

Note: Values in the same row that do not share subscripts are statistically different at the 5\% level, between non-participants and participants.

${ }^{\mathrm{c}}$ On a scale of 1 , least material hardship, to 6 , greatest material hardship. 
Table 4 Comparison of subjective indicators of well-being between the EITC nonparticipating and participating rural mothers

\begin{tabular}{lcc}
\hline & Non-Participating & Participating \\
\hline Income not enough to live on (\%) & $38.0_{\mathrm{a}}$ & $24.8_{\mathrm{a}}$ \\
$\begin{array}{l}\text { Income just adequate (\%) } \\
\text { Income more than adequate (\%) }\end{array}$ & $48.1_{\mathrm{a}}$ & $56.6_{\mathrm{a}}$ \\
& $13.9_{\mathrm{a}}$ & $18.6_{\mathrm{a}}$ \\
$\begin{array}{l}\text { Current economic situation worse than two years } \\
\text { ago (\%) }\end{array}$ & $29.1_{\mathrm{a}}$ & $18.6_{\mathrm{a}}$ \\
$\begin{array}{l}\text { Current economic situation about same as to years } \\
\text { ago (\%) }\end{array}$ & $22.8_{\mathrm{a}}$ & $20.7_{\mathrm{a}}$ \\
$\begin{array}{l}\text { Current economic situation better compared to } \\
\text { two years ago (\%) }\end{array}$ & $48.1_{\mathrm{a}}$ & $60.7_{\mathrm{a}}$ \\
$\begin{array}{l}\text { Satisfaction with life } \\
\text { c (mean) }\end{array}$ & $3.7_{\mathrm{a}}$ & $4.0_{\mathrm{b}}$ \\
\hline
\end{tabular}

Note: Values in the same column that do not share subscripts are statistically different at the 5\% level, between participants and non-participants.

${ }^{\mathrm{c}}$ On a scale of 1 , very dissatisfied with life, to 5, very satisfied with life. 
Table 5 Comparison of selected measures of macroeconomic conditions between the EITC non-participating and participating rural mothers

\begin{tabular}{lcc}
\hline & Non-Participating & Participating \\
\hline Index of relative rurality ${ }^{\mathrm{c}}$ (mean) & $0.52_{\mathrm{a}}$ & $0.47_{\mathrm{b}}$ \\
Living in a state without state EITC (\%) & $43.0_{\mathrm{a}}$ & $65.5_{\mathrm{b}}$ \\
Living in a state with state EITC (\%) & $57.0_{\mathrm{a}}$ & $34.5_{\mathrm{b}}$ \\
& & $69.0_{\mathrm{a}}$ \\
Living in a state without refundable state EITC (\%) & $68.4_{\mathrm{a}}$ & $31.0_{\mathrm{a}}$ \\
\hline Living in a state with refundable state EITC (\%) & $31.6_{\mathrm{a}}$ \\
\hline
\end{tabular}

Note: Values in the same column that do not share subscripts are statistically different at the 5\% level, between participants and non-participants.

${ }^{\mathrm{c}}$ With 0 representing the most urban place and 1 representing the most rural place (Waldorf, 2007). 